\title{
A History of Violence in the French Revolution
}

\section{P. Gueniffey}

For citation: Gueniffey P. A History of Violence in the French Revolution. Vestnik of Saint Petersburg University. History, 2018, vol. 63, issue 3, pp.908-916. https://doi.org/10.21638/11701/spbu02.2018.315

The aim of the French Revolution was to reform the Old Regime of absolute monarchy according to the principles of Enlightenment. It succeeded but also brought about terrible fits of violence. This contradiction had always challenged the judgement of the contemporary witnesses as well as the reflection of subsequent historians. Was it the result of a fortuitous drift due to the circumstances (fierce resistance of the counter-revolution, unexpected conflict with the Church, unwished wars with European monarchies)? Was it an expression of the barbaric standards of the people under the Old Regime? Or was it a necessary consequence of the very option of a radical rational revolution? This article demonstrates that violence was inevitable but the circumstances made it much worse. Four unexpected events contributed to the radicalization of the Revolution: the decree of the $27^{\text {th }}$ November 1790 on the reorganization of the Church; the flight of Louis XVI to Varennes (20-21 June 1791); the election of inexperienced new deputies in the Legislative Assembly which succeeded the "Constituante" in October 1791; the declaration of the war to Austria on 20 th April 1792. Nonetheless, above all, in a completely new context the competition for power and the ill-fated role played by a limited group of publicists triggered, the disastrous spiral which led to the Terror.

Keywords: French revolution, violence, Terror, publicists, Robespierre, Marat.

\section{История насилия в ходе Французской революции}

\section{П. Генифбе}

Для цитирования: Gueniffey P. A History of Violence in the French Revolution // Вестник Санкт-Петербургского университета. История. 2018. Т. 63. Вып. 3. С. 908-916. https://doi. org/10.21638/11701/spbu02.2018.315

Цель Французской революции состояла в преобразовании абсолютной монархии старого порядка в соответствии с принципами Просвещения. Революционеры преуспели в достижении заданной цели. На смену старому политическому и социально-экономическому режиму пришло новое государственное устройство, однако достижение намеченных преобразований сопровождалось ужасающими вспышками насилия. Явное противоречие между благородными посылами и низменными средствами их достижения всегда вызывало интерес со стороны как современников, непосредственных сви-

Patrice Gueniffey - Doctor in History, Professor, The Graduate School of Social Sciences (École des Hautes études en Sciences sociales - EHESS), 105, blvd. Raspai blvd., Paris, 75006, France; patrice.gueniffey@gmail.com

Патрис Гениффе - д-р ист. наук, проф., Высшая школа социальных наук, Франция, 75006, Париж, Бульвар Распай, 105; patrice.gueniffey@gmail.com

My sincere thanks to T. N. Goncharova who translated this article from French into English.

(c) Санкт-Петербургский государственный университет, 2018 
детелей событий, так и последующих историков. Можно ли объяснить это противоречие случайным отступлением от идеалов буржуазно-демократической революции, продиктованным силой обстоятельств (ожесточенное сопротивление контрреволюции, неожиданный конфликт с церковью, незапланированные войны с европейскими монархиями)? Или же упомянутое противоречие явилось выражением варварских нравов людей, выросших и сформировавшихся при старом порядке? Или его следует считать необходимым следствием самого выбора радикальной рациональной революции как инструмента борьбы с изжившими себя государственными устоями? Автор статьи показывает, что насилие было неизбежным, но обстоятельства придали ему грандиозный масштаб. Четыре непредвиденных события способствовали радикализации революции: Декрет от 27 ноября 1790 г. о гражданском устройстве духовенства; бегство Людовика XVI в Варенн (20-21 июня 1791); избрание неопытных депутатов в Законодательное собрание, пришедшее на смену Учредительному в октябре 1791 г.; объявление войны Австрии 20 апреля 1792 г. Тем не менее приходится констатировать, что в наибольшей степени в том совершенно новом контексте, в котором пребывали революционеры, именно борьба за власть и злополучная роль немногочисленной группы публицистов имели следствием катастрофическую спираль, которая привела к Террору.

Ключевые слова: Французская революция, насилие, Террор, публицисты, Робеспьер, Марат.

François-Noël Babeuf who was not yet known as Gracchus, happened to be in Paris at the time of the storming of the Bastille. He saw the first acts of violence of the French Revolution. He saw the mob lynch the governor of the fortress and flood the streets of Paris. He, who was to be a prophet of communism, was astonished by so much savagery. He could understand the delight of those who howled at the victims, who had been their "oppressors", when they went by, but he could not share it. He writes to his wife a few days later: "So much joy made me sick! I was at once satisfied and displeased... I do approve of such justice when it contents itself with the suppression of the guilty, but how should it not be cruel today? Such a variety of torments, quartering, torture, the wheel, the stake, flogging, the gallows, executioners everywhere, have given us such bad morals! Instead of civilizing us, the masters have made us barbarous because they are themselves barbarous" ${ }^{\text {. }}$

There is a well-known word by Talleyrand, according to whom, one could have no idea of "la douceur de vivre", if one had not lived in the last years of the Ancien Régime. It might be true if he meant the society Talleyrand knew and moved in. Beneath the thin veneer of the exquisite social habits of the Siècle des Lumières lay violence. If there was such a trauma in July 1789, and again in October, when a mob came from Paris to attack the Palace in Versailles and slaughtered several guards, this is because the urban ruling class had long forgotten how brutal country people and town workers could be. Two worlds had existed side by side, ignoring one another; even two different humanities, according to the philanthropist Artur Young, who visited France on the eve of 1789. And yet a foreboding event could have provided a warning: the riot which sacked the Réveillon wallpaper factory in April 1789. The soldiers had much trouble repressing the rioters, dozens of whom died.

${ }^{1}$ Lettre de Babeuf à sa femme du 23 juillet 1789 // Advielle V. Histoire de Gracchus Babeuf et du

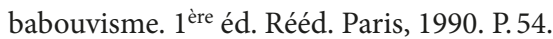


But it was all forgotten in the wake of the meeting of the General States. Everyone revelled in optimism, under the illusion of the society which had united around the king and the delegates of the nation. Few people understood which forces had been liberated in the hectic days of the spring and summer, and how difficult it would be to control them in the future. For men like Babeuf, such unfortunate events were just a consequence of the past, which would soon be mitigated by enlightened politics, well-calculated reforms, amendment of injustice and education of the people.

As the months passed, however, one had to face the facts. Far from receding, violence rose everywhere. But as late as 1792, Rabaut-Saint-Etienne, a member of the Constituent Assembly who would be guillotined a few months later, said it again loudly and clearly: it was not the revolution which should be made responsible for so many victims, but what remained of poverty and barbary in French society. In other words, the Ancien Régime was concerned, not the Revolution, and if the Revolution took another course than first imagined, its principles, its ideals, its values were not questioned. The blood that had been shed proved nothing; it rather gave an additional justification to the Revolution, which would ultimately eradicate the very root all causes of violence ${ }^{2}$. Even Condorcet kept by the same theory until his suicide in 1794: the inheritance of the Ancien Régime explained everything, whereas the Revolution was not guilty of the crimes perpetrated in its name.

It was a mixture of social and political violence which started before 1789 as all official structures collapsed in the turmoil of the elections to the General States. The positive political passions of the Revolution - faith in liberty and equality - covered less worthy social passions: resentment, vengeful feelings, tabula rasa conceived as the triumph of the poor over the rich. Among hundreds of newly created newspapers, the most radical ones were the most popular. "Lami du peuple" set the tone and expressed some of most powerful popular passions, not the daily newspapers which tried to start a parliamentary press in France similar to that existing in Britain. Marat was indignant, critical, pointed accusatory finger, suspected of treason those who tried if not to stop but to slow down the revolution. He was indeed the voice of the Revolution and if not the "friend" of the people, at least the interpreter of their instincts. More than the politicians, deputies or Jacobins, a small group of the journalists bore a heavy responsibility for the early drift of the Revolution. Words cost nothing to journalists, but they can bring them quite a lot. They were a crowd of adventurers or embittered people who found an opportunity to assuage their hatred and, perhaps, to build a fortune. They would not have played such a part if the times of Enlightenment had not put the writer on a pedestal and made him the voice of public opinion. The political discussion had taken a literary color which was to be of great consequence during the Revolution. "The people imbibed the temper and disposition of the authors with their principles. $<\ldots>$ The whole nation acquired, by dint of reading them, their instincts, their mental complexion, their tastes, and even their natural defects. When the time for action came, men dealt with political questions on the basis of literary principles. The student of our revolution soon discovers that it was led and managed by the same spirit which gave birth to so many abstract treatises on government. In both he finds the same love for general theories, sweeping legislative systems, and symmetrical laws; the same confidence in theory; the same desire for new and original institutions.

${ }^{2}$ Rabaut-Saint-Etienne J. P. Précis historique de la Révolution française. Paris; Strasbourg, 1792. P. 6-7. 
$<\ldots>$ A terrible sight! For what is a merit in an author is often a defect in a statesman, and characteristics which improve a book may be fatal to a revolution"3.

Since Voltaire the writers had come to the fore, and this was true not only of Voltaire or Diderot, but also of those who grew later like weeds in the shade of the giants: Fréron, Marat, Hébert, Camille Desmoulins. At a time when public opinion, which the writers claimed to represent, had become a principle, and the people - a source of all truth and all legitimacy, one cannot wonder if a profession so little respected - and usually despised, as Max Weber wrote later - as that of the journalists, played such a part well beyond its own triviality. So that beside the barbarous, uneducated, almost wild people, whose outbursts of violence punctuated the course of the Revolution, other barbarians, educated ones, stirred up the fire, doing their best to push up the Revolution. As a disappointed Barnave confessed, short before being executed, the moderate had never had the least influence on the events, staying always behind and vainly trying to hold up the march of the revolutionary column which they could but follow reluctantly ${ }^{4}$.

However, the steady rising of violence did not result only in a mechanical process of radicalization. Circumstances played a decisive part too. They increased fears as well as the temptation to find scapegoats for whatever did not work, that is, for almost everything. Four occurrences which brought about the violent course of the Revolution were of special importance ${ }^{5}$.

First, it was the decree of 27, November, 1790, that compelled all members of the clergy to swear fidelity to the Constitution, which appeared schismatic to many of them, including those who had approved of the reorganization of the Church and the nationalization of Church estate. This fateful decision added to the political passions unleashed by the Revolution, those passions which are inherent to religious convictions. As a result, the men of 1789 had to go the way of violence, so massive was the refusal to take the oath.

The second event was the flight of the king to Varennes (20-21 June 1791) which opened the question whether the monarchy should be maintained or not. It created an abyss under the feet of the deputies at the very moment when the National Assembly was on the verge of closing its work and giving France its first constitution.

The third unfortunate circumstance was the almost incomprehensible fact that the deputies decided on the $16^{\text {th }}$ May 1791 to exclude themselves from their own succession. To remove from the new institutions those who had written the Constitution and acquired in the last three years an irreplaceable experience was to put the destiny of France in inexperienced hands, but also in the hands of all those who, in newspapers or clubs, made no mystery of their intention to overturn a Constitution which they found to be not revolutionary enough and too accommodating to the past.

Last but not least, the declaration of the war to Austria, on 20 April 1792, swept along not only the monarchy — Louis XVI and Marie-Antoinette were suspected to have

3 Tocqueville A. de. The Old Regime and the Revolution / transl. by John Bonner. New York, 1856. P. $179-180$.

${ }^{4}$ Gueniffey P. Terminer la Révolution ? Barnave et les feuillants // Gueniffey P. Histoires de la Révolution et de l'Empire. Paris, 2011. P. 151.

${ }^{5}$ Gueniffey $P$. La politique de la Terreur: essai sur la violence révolutionnaire 1789-1794. Paris, 2000 (russian edition 2003). 
secret communications with the enemy, which was not false-, but the very possibility of bringing the Revolution to an end.

After the fall of the monarchy (10 August 1792), the Constitution of 1791 did not mean anything more. Another one was written by the "Convention Nationale" but it was not even tried: after being solemnly adopted, it was locked up in a cedar ark and shelved till the peace. As the country was invaded from all sides, that meant forever. Since the massacres perpetrated in the prisons in September 1792, Revolutionary France had changed. Indeed, there was an assembly, which possessed great theoretical powers. In fact, it fulfilled none. Authority was in the hands of a whole series of more or less official committees, competing with one another and largely ignoring the instructions they got from Paris - from the Convention, the ministers, the "députés en mission" and even from the "Commune de Paris" who had become since September 1792 a State in the State.

In this anarchical context where, according to Barras, one guillotined for fear of being guillotined, the "Tribunal révolutionnaire" appears first as an island of wisdom. It will change. Several generations of revolutionaries have already disappeared: "monarchiens" of 1789, "feuillants" of 1791, "girondins" of 1792, "enragés" of 1793. The revolutionary stage empties, the prisons are full of suspects, captured emigrés, priests and all those who a neighbor or debtor wants to get rid of. The time of the great massacres has started in Lyon, Toulon, the Vendée. The figures are controversial. One speaks of 40000 victims. But this does not take into account all the victims of the civil war in the West, summary executions, drownings, grapeshot shooting or the "infernal columns" of general Turreau. Altogether, if one adds to the victims of the repression those of the civil war in the West, a figure of 300000 victims is more likely.

The Revolution had lost its compass. How can it be explained? The circumstances, of course. Then, the obliteration of public authority that had been so long associated with the person of the king: becoming democratic, it had not recovered its capacity of arbitrating conflicts and imposing rules. But these factors are not sufficient enough to properly explain the drift of the Revolution, nor is the existence of an ideology of violence, to which the supporters of Counterrevolution have always tried to reduce the Terror.

Of course, rebuilding society on a new rational basis without any relation to the past or to tradition was fraught with violence. "Our history is not our code" proudly proclaimed Rabaut Saint-Etienne in $1789^{6}$. Such principles meant a total rupture with ancient institutions, long-established habits. It meant uprooting immemorial beliefs and ingrained practices, and teaching new ones to the people who were to be reinvented, so to speak. That could not have been done without using force. Edmond Burke predicted as soon as 1790 , in the midst of what is considered the "happy year" of the Revolution, the year of the "Fête de la Fédération", that France was running if not towards disaster, at least towards unheard-of violence ${ }^{7}$. The revolutionary passions, voluntarism - the idea that there is no limit to the efficiency of human will - and artificiality - the idea that a society resembles a soft dough and can be shaped and reshaped from the basis to the top upon purely rational principles - such ideas would soon lead to massacres perpetrated in the name of an abstract People against the real people. The following events proved Burke was right.

${ }^{6}$ Rabaut-Saint-Etienne J.P. Considérations sur les intérêts du Tiers État adressées au peuple des provinces par un propriétaire foncier. $1^{\text {ère }}$ éd. 1788. Nouvelle édition. Paris, 1826. P. 11.

7 Burke Ed. Reflections on the Revolution in France. London, 1790. 
Yet the use of the word "ideology" cannot explain much in this case. According to Alain Besançon, "ideology is a systematic doctrine which promises hail to the converted; which gives itself as consonant with a cosmical order; which claims scientific certainty; which determines a political praxis aiming at a total transformation of society in conformity with its immanent model which the doctrine has discovered. The field of ideology is politics. It is a dated phenomenon, the genesis of which needed exceptional circumstances"8.

But does not the French Revolution promise hail through history, a promise which can lead to much violence through the absolution of the present crimes by the happy future? This is true but those times ignore the science of society even in the degraded form of slogans, they ignore the necessary complement of ideology, its practical form - the party. Nothing is more distant from Bolshevism than Jacobinism. The latter never built a party invested with a doctrine and a discipline of action. Jacobinism is inferior to its reputation. It never embodied itself in a party: it is more the field or the stage on which parties and factions confront themselves to get hold of the legitimacy which Jacobinism embodies due to the circumstances of the birth of the first clubs in 1789; and to achieve, armed with this legitimacy, their special purposes. There is a Jacobine discourse, but it is not homogeneous and can't become a doctrine. Its object is not the nature of democracy: it is more the means of the Revolution than its ends.

In the light of this, the Jacobins of 1793 keep to the principles of 1789: to use Marxist words, the bourgeois society, individualist and liberal, remains their horizon, even if at various points, the tone will be more "social". The Jacobine discourse on individual and sovereignty is in reality a discourse on Revolution and, more precisely, on Revolution as total war with no other outcome than "victory or death". It is a discourse on democracy at war that brings the principles of democracy — rights of individuals, liberty, rule by law, separation between between the public and private spheres - to such a degree of incandescence that in the end they reverse into the opposite. War, according to Tocqueville, kills democracy. Not only because it necessarily increases the power of the government, but also because by making people get used to violence and servitude, it eventually leads to despotism. War actually means enlistment, giving up every form of autonomy and individual reason. War creates a social order in which the individual does not exist anymore, an order in which the individuals by renouncing themselves, giving up all that distinguishes and separates them in normal times, achieve a sort of absolute equality. The Jacobine discourse is the theory of the democratic individual thrown into a total war without any possible negotiated outcome? .

That brings us to the last factor among the possible explanations of the Terror. The French Revolution, as most revolutions, started with a proliferation of speeches. As if before pouring blood, the revolutions had to produce words, speeches, a flood of speeches, all the more radical as they don't have to submit to the requirements of reality. This stream of words deals only with one thing: the nature and aims of the Revolution. As a result, all these speeches go one way: that of a constant overbid. The word "Revolution" has no steady meaning. It is a vague promise of liberty and happiness that opens an unlimited

8 Besançon A. Les origines intellectuelles du léninisme. Paris, 1977. P. 143.

9 Cochin A. Les sociétés de pensée et la démocratie moderne: études d'histoire révolutionnaire. Paris, 1921; Kennedy L. M. The Jacobin clubs in the French Revolution. Princeton, 1982. See also: Furet F. Penser la Révolution française. Paris, 1978. P. 212-259. 
space to speculation. Every new definition of the Revolution, as soon as it is formulated, can be challenged by other definitions that will radicalize its aims. There lies the cause for the revolutionary "hubris" which, through a series of overbids in the definition of the aims and the choice of the means, leads to violence through a dynamical process of cumulative radicalization of the discourse.

All these speeches emulating in violence tend to occupy the most advanced position in order to conquer legitimacy and get hold of power. The only justification for power, in this context, is the ability to impose one's interpretation of the meaning of the Revolution as the only true and legitimate one. A fragile justification, since it can be contested in the name of other, still more true and legitimate definitions. As a result, each of the competing actors must constantly occupy the most advanced position in order to overtake the others: each one must continuously justify himself by demonstrating in words and actions that he is more revolutionary than the most revolutionary among his rivals. Outbidding is a necessity, and violence - a necessary consequence inasmuch as one outbids to the detriment of the enemies, real or alleged, of the Revolution.

Adrien Lezay-Marnésia gave a vivid description of such dynamics: "Popularity is the greatest force of popular parties, and persecution of the adverse party - the best means of popularity. No wonder that they rivaled for popularity, and that rivalry made war all the more determined against all enemies of the Revolution. Everyone, in order to get more popular than his rival, had to outdo him in violence, and the vanquished, to clear himself of the suspicion of complicity which his rival would throw on him, tended to overbid him in severity" 10 .

Competition for power through conquest of revolutionary legitimacy is all the more ferocious as since 1792, the French revolution was not restricted by any form of legality, since after overthrowing the Ancien Régime, it overthrew the constitution it had elaborated with such pains. Together with that constitution, the very idea of law had collapsed. The insurrection of 10 August 1792 had substituted the reign of force with that of the law. Overthrowing a constitution by violence means devaluating from the start every future legality and setting as a principle that the will of the people, or rather the will of those who claim to speak in its name, is superior to any contract or commitment: what has been overthrown today will be overthrown tomorrow for the same reason.

From now on, no procedure whatsoever determines the way to confer power: it belongs to those who know how to present themselves as the embodiment of revolutionary legitimacy. Moreover, it is not only some authority, defined by the constitution or laws, which can be taken, but unlimited power, since the monarchy has been overthrown. The collapse of legality, added to the opening of an unlimited space to ambitions, lets violence loose. Every party can hope to take the prize, but once it is won, it is not protected anymore by law, so various competitors, being unable to produce an unquestionable title for their supremacy, must destroy rival claims, proving by their own excesses that their rivals are moderate and false revolutionaries.

The French Revolution has invented - at least partially - the modern idea of revolution: permanent; independent of the ends it has given itself; conceding legitimacy only to the most radical of its protagonists.

${ }^{10}$ Lezay A. Des causes de la Révolution et de ses résultats. Paris, An V-1797. P. 22. 
It had started with a view to "regenerating" France, which meant bringing order into its government and giving it laws. Now it had no other purpose than itself, attacking religion, considering taking children from their parents to make them citizen soldiers like in Sparta, making the use of the "tu" compulsory, destroying every symbol of the Ancien Régime, wrecking the royal graves in Saint-Denis, killing in a measure unseen since the religious wars in the $16^{\text {th }}$ century. Caricatures of the time show France turn into a large cemetery and the executioner forced to behead himself because there are no clients left.

This situation could have lasted a long time if the Terror itself had not provided a solution. In March and April 1794 Robespierre who until then had always avoided moving away from the most extremist, suddenly exposed himself and stroke. He had a good reason: the Hebertist faction wanted to "dechristianize" France, and attacked him personally, as he believed religion was necessary to social order. With the help of Danton he put an end to the antireligious masquerades and then, using Danton against Hebert and Hebert against Danton, he sent both to the scaffold.

Posterity has not acknowledged enough this great political coup which threw Robespierre into power and permitted him to concentrate all the means of power within a few weeks. From April to July 1794, he could exercise a real dictatorship, and Napoleon who was quite a Robespierrist at the time - would keep on asserting he succeeded where Robespierre had failed. The difference is that Napoleon could lean on the military, whereas Robespierre had to count on committees and militants, many of whom had sympathized with Hebertism. Moreover, Bonaparte knew what he wanted when he snatched power. No one knows what the exact intentions of Robespierre were; he took the secret with him into his grave. All he did was to start a fight against those who, like Carrier and Fouché, had "exaggerated" the terrorist measures. He took control of the repressive system and passed a bill - known as the act of 22 Prairial, 10, June, 1794 - which centralized justice in Paris, mechanically increasing the number and the rhythm of the executions. This weapon was essentially intended to eliminate one day all kind of opposition or resistance inside the National Convention, because the act of 22 Prairial suppressed all form of parliamentary immunity. At the same time, as the military situation suddenly improved, Robespierre, who could not justify his dictatorship by circumstances anymore, appealed to religion and the will of God. His colleagues saw in it a vague and indefinite menace. Would he kill all the atheists as some of his lieutenants suggested?

In the end, did he wish to end the Revolution by ensuring for himself a monopoly of terror, or was he swept away by the utopia of a virtuous society from which all the wicked would have been removed? Was he a profound politician or a fanatical revolutionary messiah? The question is still open, and the mystery of Robespierre's personality and action remains ${ }^{11}$.

Once the Incorruptible was dead, the Terror was doomed. Robespierre was so closely associated with the idea of revolution, he embodied so purely the image of "Revolution's excess", according to Michelet, that no one could succeed him. There could not be a "new Robespierre". By his virtuous rhetoric, he tried to give a new future and a new aim to the French Revolution: not only to destroy the old world, but to create a new man. But while he celebrated the new cult dedicated to the Supreme Being and his own idea of the perfect republic, the circumstances radically changed. The French armies, which had been de-

11 Gueniffey P. Histoires de la Révolution et de l'Empire. Paris, 2011. Ch. VII and VIII. P.217-302. 
fending the threatened borders for a long time, now settled in Amsterdam. The Fatherland was no longer in danger. It was no more 1793. Of course, it was not yet over with violence. There were retaliations, new purges. The spirit of civil war had gone too far, the spirit of institutions could not easily get the upper hand. In 1793, in the course of a harsh debate in the Convention, Legendre, who had been a butcher, tried to tear Lanjuinais down from the platform. "I will stun you like an ox if you don't come down", said he. - "You should first decree that I am an ox", replied Lanjuinais ${ }^{12}$.

One had come so far. It is not surprising that fifteen years of authoritarian Bonapartist regime were necessary, after ten years of Revolution and turmoil, to put an end to that queer habit of killing one another that had taken possession of the French.

\section{References}

Besançon A. Les origines intellectuelles du léninisme. Paris, Calmann-Lévy Publ., 1977, 327 p.

Cochin A. Les sociétés de pensée et la démocratie moderne: études d'histoire révolutionnaire. Paris, Plon Publ., $1921,300 \mathrm{p}$.

Furet F. Penser la Révolution française. Paris, Éditions Gallimard Publ., 1978, 259 p.

Gueniffey P. Histoires de la Révolution et de l'Empire. Paris, Perrin Publ., 2011, 744 p.

Gueniffey P. La politique de la Terreur: essai sur la violence révolutionnaire 1789-1794. Paris, Fayard Publ., $2000,376 \mathrm{p}$.

Kennedy L. M. The Jacobin Clubs in the French Revolution. Princeton, Princeton University Press, 1982, $384 \mathrm{p}$.

Slavin M. The Making of an Insurrection. Parisian Sections and the Gironde. Cambridge, Harvard University Press, 1986, 256 p.

Received: 04.02.2018

Accepted: 31.05.2018

12 Slavin M. The Making of an Insurrection. Parisian Sections and the Gironde. Cambridge, 1986. P. 110 . 